\title{
Public Procurement Act 2007 and Economic Growth in Nigeria: South-South Perspective
}

\author{
Omekwe, Sunday Omiekuma \\ Department of Economics, Faculty of Social Sciences, University of Port Harcourt
}

\begin{abstract}
Economic development may be achievable through efficient and effective allocation of resources. In same vein, effective and cost effective resource allocation can only be powered by an equally 'effective and transparent' procurement process or system. Accordingly, the PUBLIC PROCUREMENT ACT 2007, was established to among other reasons, midwife an effective procurement system for the country that will ensure value for money for resource allocation. Annual capital expenditure provision in national budgets for the last five years had averaged about 24.7\%. Records available from the Bureau of Public Procurement (midwife of the Act) indicated that the South-South geo-political zone did enjoy (probably not commensurate with her resource contributions) part of these national budgetary allocations. Analysis of same records, unfortunately showed that the intent to achieving value creation and development in the area could not have been achieved, for many reasons including, inadequate provisions and allocations, poor conception/implementation/execution, inadequate monitoring for the referenced restive region. Given the findings above, it is therefore suggested amongst others that there should be establishment of strong and compelling institutions, amidst the pervading corruption that has become Nigeria socio-cultural value. Also, there should be domestication of public procurement law by all the 36 states and the entire 774 local governments in Nigeria. All these will contribute towards an effective creation of 'value for money' in resource allocation for desired regional economic development.
\end{abstract}

Key Words: Bureau, Public, Procurement, Act, Economic Growth, South-South

\section{Introduction}

Public procurement plays a significant role in the administration, size and policy of most economy in the World. Every year the Federal Government of Nigeria prepares annual budgets (Recurrent, Capital and Special provisions) for its expenditure framework. Capital and some special budgets are usually for procurement for infrastructure or enablers of development. The legal framework for public procurement is contained in the Public Procurement Act 2007 (PPA), and driven by the Bureau of Public Procurement (BPP). Records obtained from the Bureau of Public Procurement shows that the South-South geopolitical zone (region), made of the six states of Akwa Ibom, Bayelsa, Cross River, Delta, Edo, and Rivers, during the period under review, had their share of the capital provisions like other geopolitical zones, administered through government Ministerial Departments and Agencies (MDAs), after clearance by the BPP for certain procurement thresholds. The objective of this paper is to examine the effect of capital budgets on the South-South (SS) region of Nigeria.

\section{The South-South Geopolitical Zone}

The South-South (SS) Geopolitical, one of six in Nigeria, is made up of the States of Akwa Ibom, Bayelsa, Cross River, Delta, Edo, and Rivers. These six contiguous states occupy 94,587km2 of Nigeria's 923,768 km2 land mass. According to the 2006 census, the region had about $21.01 \mathrm{~m}$ inhabitants representing approximately $15 \%$ of Nigeria's population of $140.43 \mathrm{~m}$ projected estimates for 2016 had the region's population at $28.82 \mathrm{~m}$ and 
$178.50 \mathrm{~m}$ for the Nation (see Table 1). The region is home to more than $90 \%$ of Nigeria's proven oil and gas reserves, and therefore contributes more than $90 \%$ of Nigeria's foreign earnings. Though some oil/and gas related establishments are sited within the region, the people are predominantly subsistence farmers and fishermen. The region's major cities are Port Harcourt, capital of Rivers State, Calabar, capital of Cross Rivers State, Uyo, capital of Akwa Ibom, Benin, capital of Edo State, Warri of Delta State and the traditional settlement of Yenagoa, which serves as the capital of Bayelsa State.

Table 1: South-South Population and GDP

\begin{tabular}{|l|l|l|l|}
\hline State & Population (2006) & Projected Population (2016) & GDP \\
\hline Nigeria & $\mathbf{1 4 0 , 4 3 1 , 7 9 0}$ & $\mathbf{1 7 8 , 5 0 0 , 0 0 0}$ (approx.) & \\
\hline Akwa/Ibom & $3,902,051$ & $5,482,177$ & $11,179,000.00$ \\
\hline Bayelsa & $1,704,515$ & $2,277,961$ & $4,337,000.00$ \\
\hline Cross River & $2,892,988$ & $3,866,269$ & $9,292,000.00$ \\
\hline Delta & $4,112,445$ & $5,663,362$ & $16,749,000.00$ \\
\hline Edo & $3,233,366$ & $4,235,595$ & $11,888,000.00$ \\
\hline Rivers & $5,198,716$ & $7,303,924$ & $21,073,000.00$ \\
\hline Total & $21,044,081$ & $28,829,287$ & $74,518,000.00$ \\
\hline
\end{tabular}

Source: National Population Commission, National Bureau for Statistics

\section{Public Procurement and Economic Development public}

Procurement deals with how goods and services are secure in the interest of public authority. Thus, public procurement covers all works and contracts of public authority with the exception of military acquisitions which account for huge some of public financing. The Great Britain Procurement Act (GPA) and the European Union (EU) procurement laws allow of exceptions, where public tendering would violate a country's essential security interests. Additionally, certain interventionist, politically or economically sensitive procurements may also be treated differently.

The enablers of development are pivotal to any economy. The 'enablers' entail the critical infrastructure needed to achieve meaningful economic growth and development in any nation. Enablers such as power, transportation, science and technology, and equitable justice must be available and of sufficient quality to propel economic growth and development. According to Dada, Okikiolu \& Oyediran (2006), infrastructure development remains a sine-qua-non to national development regardless of the method used to procure projects.

According to Reich, (2009) as well as Wahab and Lawal (2011) public procurement is very crucial to global economy that makes developing nations spent the minimum of $10 \%$ and maximum of $30 \%$ on public procurement. In like manner, Thai (2005) as well as Familoye, Ogunsemi \& Awodele (2015) affirms that the magnitude of the procurement expends influence critically on the nation and its effect is challenges. The global effort to achieve economic development is a goal of the United Nations, the World Bank, Intra-continental, multilateral and bilateral development agencies. In order to achieve development as expected, the development agencies recommend that appropriate measures be put in place to effectively and efficiently apply scare resources to achieve 'Value for Money'.

The United Nations, the World Bank and indeed all other world bodies have so established effective and efficient procurement systems. The World Bank, in addition, also administers outreach programs to help governments and private organisations to strengthen their procurement systems. In the global private sector, most international blue chip organisations, have heeded the call by the World Bank to establish distinct and semi-autonomous desks or systems to handle procurements.

\subsection{Public Procurement in Nigeria}

Locally, Nigeria has had a long history of tinkering with the critical public matter of getting her procurement system right. The World Bank plays a significant role in the reformed PPA 2007 in Nigeria (William-Elegbe, 2016). In 1999, there was a clear understanding by the government that weaknesses in the existing procurement 
system were contributing to the nagging issue of corruption (Jacob, 2010). The World Bank Country Procurement Assessment Report (CPAR) revealed that Nigeria was losing an average of \$10 Billion (Ten Billion United states dollars) annually due to various abuses associated with public procurement and contract awards. It is reported that N40 out of every N100 was lost through various malpractices in procurement in Nigeria before the enactment of the PPA. Though the president Olusegun Obasanjo administration did set up the Budget Monitoring and Price Intelligence Unit (BMPIU) as a stop-gap measure, in the absence of legal framework, Nigeria's public procurement was not formally regulated at the federal, state or local government levels, until 2007. Government obviously realized that sound public procurement policies and practices are among the essential elements of good governance. It was further realised that good procurement practices reduce costs and produce timely results, whereas poor practices lead to waste and delays and often lead to allegations of corruption and government inefficiency. The passage of the PPA brought a sense of regulation or framework to the procurement process. Thus Nigeria became one of the African countries with a new legal framework for public procurement, meeting the benchmarks described by the African Development Bank Concept note.

Ten years into the application of the PPA, and the reluctance by the States and Local Governments to domicile of same, the law has received various assessments. For example, Ossai (2014) observed that the apparent successes attained at the federal level as a consequence of Public Procurement Law 2007 are taking too long for replication by across the geopolitical zones in Nigeria. It is disheartening to note that no single local government in Nigeria deemed it fit to pass public procurement edict despite the volume of money that are expended in Nigerian by local government system.

\section{The Public Procurement Act of 2007 and the Bureau of Public Procurement}

The existing government policies and practices by regulating, setting standards and developing the legal framework and professional capacity for public procurement in Nigeria; and other related matters, was made on $4^{\text {th }}$ day of June, 2007. The core Objectives of the Public Procurement act are Economic Efficiency, Competition - Providing level playing ground for all strata of bidders, Value for money, and Transparency.

\subsection{The Procurement Process by the Bureau of Public Procurement (BPP)}

Procurement of goods and services are administered by MDAs according to thresholds. The BPP has published procurements methods, and has also established basically five levels of contract awards for works and thresholds at the Federal level (except for NNPC) as shown in table 2 below

Table 2: Works' Threshold Approval

\begin{tabular}{|c|c|c|c|}
\hline $\mathrm{s} / \mathrm{n}$ & Value of works & Approving Authority & $\begin{array}{l}\text { BPP Certificate of no } \\
\text { objection }\end{array}$ \\
\hline 1 & N1billion and above & Federal Executive Council & $\begin{array}{l}\text { Issues 'Certificate of no } \\
\text { Objection' }\end{array}$ \\
\hline 2 & $\begin{array}{l}\text { N10m and above, but less } \\
\text { than N1b }\end{array}$ & Ministerial Tenders Board & No \\
\hline 3 & $\begin{array}{l}\mathrm{N} 5 \mathrm{~m} \text { and above but less } \\
\text { than } \mathrm{N} 250 \mathrm{~m}\end{array}$ & Parastatal Tenders Board & No \\
\hline 4 & Less than N10m & Accounting Officer - Permanent Secretary & No \\
\hline 5 & Less than N5 & Parastatal or Agency CEO or Director & No \\
\hline
\end{tabular}

Source: BPP Abstract of Statistics

Though the BPP trains, posts or second procurement officers to all MDAs, procurements less than one billion Naira, are managed within the MDAs without corresponding reports by BPP, and this portends perceived and ominous danger in the negative effects of contract splitting, partial and inefficient allocation of resources. 
5. The Capital Budget of Nigeria 2012-2016

Table 3 - Nigeria Aggregate/Capital budget

\begin{tabular}{|l|l|l|l|}
\hline Year & Aggregate Budget(Nb) & Capital Budget $(\mathrm{Nb})$ & \% Capital Budget \\
\hline 2012 & 4,749 & 1,329 & 27.98 \\
\hline 2013 & 4,987 & 1,588 & 31.8 \\
\hline 2014 & 4,642 & 1,101 & 23.7 \\
\hline 2015 & 4,460 & 557.0 & 14.1 \\
\hline 2016 & 6,060 & $1,587.4$ & 26.2 \\
\hline Average & 4979.6 & 1232.48 & 24.76 \\
\hline
\end{tabular}

Source: Budget office/Bureau of Statistics

Performance or implementation of the five years under review is presented below. The average performance is $61.42 \%$

Table 4- Nigeria Capital Budget Performance

\begin{tabular}{|l|l|l|l|}
\hline \multicolumn{1}{|c|}{ Year } & \multicolumn{1}{|c|}{ Capital provision (Nb) } & \multicolumn{1}{c|}{$\begin{array}{c}\text { Capital budget implementation } \\
\text { (releases Nb) }\end{array}$} & \% performance \\
\hline 2012 & 1329.00 & 744.42 & 56.01 \\
\hline 2013 & $1,588.00$ & 912.87 & 57.49 \\
\hline 2014 & $1,101.00$ & 587.61 & 53.37 \\
\hline 2015 & 557.00 & 362.39 & 65.06 \\
\hline 2016 & $1,587.4$ & 1191.97 & 75.09 \\
\hline Average & & & 61.42 \\
\hline
\end{tabular}

Source: Budget Performance Reports by Budget office

Table 5: Value of Certificates of no Objection issued by BPP

Source: Author's compilation from published values of certificates of 'no objection' by BPP

\begin{tabular}{|l|l|l|l|}
\hline Year & $\begin{array}{l}\text { Reported national (NN) values of } \\
\text { all certificates of 'no objection' } \\
\text { issued by BPP } \mathbf{( N b )}\end{array}$ & $\begin{array}{l}\text { Reported values of 'no objection' } \\
\text { certificates issued for projects } \\
\text { domiciled in the SS (Nb) }\end{array}$ & \% of SS/NN \\
\hline 2011 & $1,121.59$ & 601.44 & 53.62 \\
\hline 2012 & $2,253.14$ & 370.04 & 16.41 \\
\hline 2013 & $1,601.39$ & 603.66 & 37.70 \\
\hline 2014 & $4,025.03$ & $1,073.73$ & 26.68 \\
\hline 2015 & 600.14 & 115.80 & 19.30 \\
\hline & $\mathbf{9 , 6 0 1 . 3}$ & $\mathbf{2 , 7 6 4 . 6 6}$ & $\mathbf{2 8 . 8 0}$ (average) \\
\hline
\end{tabular}

The issuance of a certificate of 'no objection' by the BPP is only an approval procedure recommended by the BPP for projects valued above N1b. The actual execution of projects would depend on the availability and release of funds by the Ministry of Finance and the Accountant General office. Indeed, release of funds to MDAs may be with or without cash backing, and MDAs would also comply with laid down procedures to access or utilize the funds. Therefore certificate of no objection issued is not a guarantee that a project would be 
executed. Accordingly, table 6 below, in my estimation would depict a more realistic funding of BPP reported capital projects issued certificate of 'no objection' in the SS region.

Table 6 - Estimated value of capital budget releases to the South-South (SS) Region

\begin{tabular}{|l|l|l|l|}
\hline & $\begin{array}{l}\text { Reported values of 'no objection' } \\
\text { certificates issued for projects domiciled } \\
\text { in the South South (SS) }\end{array}$ & $\begin{array}{l}\text { \% capital performance } \\
\text { from table 4 }\end{array}$ & $\begin{array}{l}\text { Estimated actual value } \\
\text { of projects in the SS }\end{array}$ \\
\hline 2012 & 601.44 & 56.01 & 336.81 \\
\hline 2013 & 370.04 & 57.49 & 212.74 \\
\hline 2014 & 603.66 & 53.37 & 322.17 \\
\hline 2015 & $1,073.73$ & 65.06 & 698.57 \\
\hline 2016 & 115.8 & 75.09 & 86.95 \\
\hline Total & $\mathbf{2 7 6 4 . 6 7}$ & & $\mathbf{1 6 5 7 . 2 4}$ \\
\hline Average & & $\mathbf{6 1 . 4 2}$ & \\
\hline
\end{tabular}

Source: Author's compilation/computations

Table 6 reveals that for the period 2012 to 2016, capital projects reported by BPP received only about N1.66 trillion, out of about N2.76 trillion expected to have been invested in the provision of much needed infrastructure or enablers of development in the region. These poor releases are attributable to poor budget performances arising from inadequate budget funding and administrative bottlenecks. This unfortunately shows that the intent to achieving value creation and the drive to development in the SS region could not have been achieved, for many reasons including:-

1. Corruption: Some high level contract-racketeering is prevalent in the MDAs. Ossai (2014) reported that $45 \%$ of companies were expected give gifts to public officials in order to secure government contracts

2. Threshold provisions and approval processes encourage contract splitting and manipulations, with a view to avoiding global reports by BPP

3. Inadequate or ineffective PPA: Some identified loopholes included ambiguity in the qualification criteria of a procurement manager, failure to provide methods for dispute resolution, no provision for effective monitoring and enforcement, etc.

4. Inadequate and absence of strong and compelling Institutions to enforce PPA

5. Inadequate provisions and allocations: Public procurement has suffered from anticipatory procurement even when procurement entity knows that there is no funding to back up such procurements. Current experiences also reveal that project funding is still anticipatory, because all funding's must be budgeted yearly.

6. Unjustifiable gap exist between budgets and actual releases, leading to underfunding, delayed completion, price escalation and project abandonment.

7. Poor conception/implementation/execution, including absence of economic cost/benefit analysis of projects

8. Restive region: A credible reason for poor project execution and abandonment is the restiveness in the region powered by militancy.

9. Lack of competition and transparency in project procurement leading to high cost of projects.

10. Projects not prioritized and harmonized, consequently, several MDAs pursue similar programs simultaneously without coordination.

11. New administrations prefer new projects to the detriment of the completion of on-going projects; they also reject maintenance/refurbishment of existing ones. Cases of government project reversals abound. 


\section{Conclusion and Recommendations}

Though a legal framework for procurement (PPA) had been established some ten years ago, its impact on the socioeconomic development Nigeria is not noticeable. In other words, the intent of the law to engender, competitiveness, transparency and value for money in resource allocation can hardly be seen to have met its mission. This is largely attributed to high level of corruption or mismanagement of public resources closely linked up with the public sector procurement systems. This is quite noticeable in the South-South, with nothing to show for its share of capital provisions. It is recommended therefore that -

1) All levels of capital procurements should be under the BPP

2) Establishment of strong and compelling institutions, amidst the pervading corruption that has become Nigeria socio-cultural value

3) Act should be centralised and allocation should be in consonance with the JAC provisions, so that allocations are not subject to political considerations

4) The domestication of public procurement law by all the 36 states and the entire 774 local governments in Nigeria promises

5) Although the Nigeria's Senate had made three proposed major amendments to the PPA in 2009, a full and thorough review be undertaken by the National Assembly to take care of all the short comings of the existing Act

6) Constituency projects are in complete negation of the procurement act, and the South- South suffers most from this arrangement.

7) Robust amendments needed to make it more reliable and effective for the procuring and delivering of assets in Nigeria.

8) Effective project monitoring and reporting for complete project life-cycle

9) Formulate realistic and credible budgets and as well release appropriate funds as at when due.

\section{REFERENCES}

[1] Dada, D., Okikiolu, O. \& Oyediran, O. (2006). A survey of public-private-partnership in Nigeria facing the effective operations of the Nigeria Procuremen Act 2007: International Journal of Economics, Commerce, and Management, 3(11), 957-968.

[2] Familoye, O., Ogunsemi, D. R., \&Awodele, O. A. (2015). Assessment of the challenges facing the effective operations of the Nigeria Procurement Act 2007. International Journal of Economics, Commerce, and Management, 3(11), 957-968.

[3] Fayomi, I. O. (2013). Public Procurement and Due Process Policy in Nigeria: Thrust, Process, and Challenges. Peak Journal of Social Sciences and Humanities.

[4] Federal Government of Nigeria. (2007). Public Procurement Act. Lagos, Nigeria: The Federal Government Printer.

[5] Jacob, O. A. (2010). Procurement law in Nigeria: Challenge for the attainment of its Objectives. Oxford University Press.

[6] Olateju, B. (1997). Report on abandoned projects. Paper presented at a national seminar organized by The Nigerian Institute of Building and Council of Registered Builders of Nigeria on consultancy practice for professional builders, Abuja.

[7] Ossai .T O. (2014) A Review of Nigeria Procurement Process. Ibadan: University Press Process, and Challenges. Peak Journal of Social Sciences and Humanities. Procurement .

[8] Ray. D. (1998) Development Economics, New Jersey, Princeton University, Press

[9] Reich, A. (2009). The New Text of the Agreement on Government Procurement: An Analysis and Assessment: Journal of International Economic Law 12 (4), 989-1022.

[10] Thai, K. V. (2004) Challenges in Public Procurement. In International Handbook of Public

[11] Wahab, A.B. \& Lawal, A.F. (2011). An evaluation of waste control measures in Construction Industry in Nigeria, African Journal of Environmental Science and Technology, 5 (3), 246-254. Retrieved from www.academicjournal.org

[12] Williams-Elegbe, S. (2016). A comparative analysis of the Nigerian Procurement Act against

[13] World Bank (2000). Country Procurement Assessment Report, Volume 1, Summary of Findings and the unresolved legal issues: African Public Procurement Law Journal, 